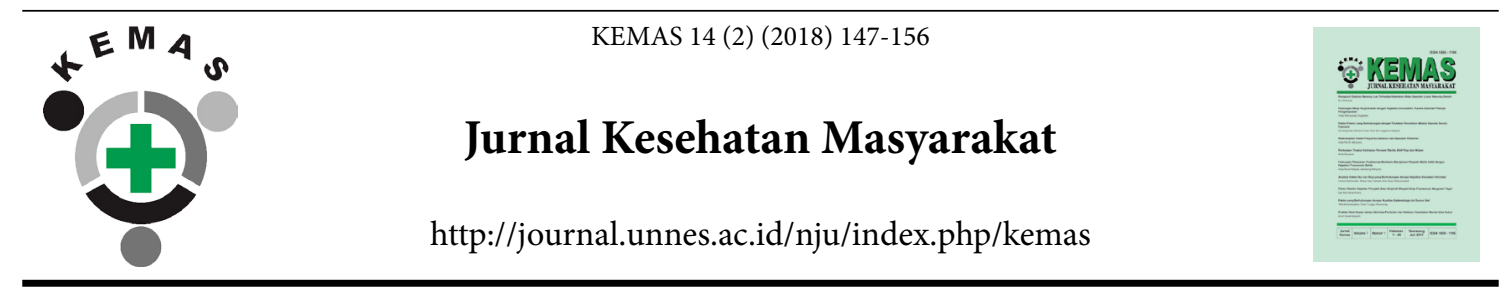

\title{
Basil leaf (Ocimmum basillum form citratum) Extract Spray in Controling Aedes aegepty
}

\author{
Denai Wahyuni $^{1 凶}$, Beny Yulianto ${ }^{1}$ \\ ${ }^{1}$ Public Health Study Program, STIKes Hang Tuah, Pekanbaru, Indonesia
}

\begin{tabular}{l} 
Article Info \\
\hline Article History: \\
Submitted November 2016 \\
Accepted August 2018 \\
Published November 2018 \\
\hline Keywords: \\
Basil, Aedes \\
aegypti, spraying \\
\hline DOI \\
https://doi.org/10.15294/ \\
kemas.v14i2.8000
\end{tabular}

\begin{abstract}
One of the efforts in population control of Aedes aegypti is by fogging, basil leaf is one of natural insecticide that can be replaced with current chemical one that are commonly used. Our aim is to measure effectiveness of basil leaf extract on Knockdown time of Aedes aegypti and effective concentration on spray usage. Twenty mosquitoes with six different intervention, each $5 \%, 10 \%, 25 \%, 50 \%$, positive control, and negative control. All intervention repeated 4 times in every 5 minutes for about 1 hour. The results will be statistically analysed using one-way Anova. Concentration of 5\% and $10 \%$ have KT50 with Insecticide Score of 1 and 2 respectively without any Knockdown concentration; concentration of 25\% have KT50 with Insecticide Score of 3 and Weak Knockdown; concentration of $50 \%$ have KT50 with Insecticide Score of 5 and Quick Knockdown. Kruskall-Wallis test $\mathrm{p}$-value $=0,001(\mathrm{p}<0,05)$ with Spearman correlation of $+0,87$ or $87 \%$. The most effective concentration on Knockdown time of Ae. aegypti is $50 \%$. The conclusion, Basil extract can be effectifely used as natural and alternative insecticide for fogging.
\end{abstract}

\section{Introduction}

Aedes sp. mosquito is vector of Dengue Fever (DF) and Dengue Hemorrhagic Fever (DHF) that has been distributed in tropical countries. It is estimated that they responsible for nearly 50 millions populations infected with DHF in 100 countries each year. There are two vectors of DHF in Indonesia, the first vector is Aedes aegypti as main vector and the second one is Aedes albopictus as potential vector. Their habitat are widespread across nation, excluding altitute $1.000 \mathrm{~m}$ above ocean level (Jacob, D. Pijoh, \& Wahongan, 2014).

DHF is infectious disease that is prevalent and unsolved health problem. It remains as a primary concern in current
Indonesia's health issues. Based on incidence rate (IR) and case fatality rate (CFR) in four decades, DHF case experiences ups and downs. In 2013, data from Ministry of Health Republic of Indonesia shows an increase of IR since 1968 to 2010 from 0.05 to 65.57 in every 100.000 people. In contrast, CFR shows a decrease from $41.30 \%$ to $0,87 \%$. This shows that effort to control the spread and management of the disease is necessary.

Until today, we still have not discovered vaccine or cure for DHF, instead the main effort to control the disease is focused on controlling the vectors that is Ae. aegypti (Linnaeus) and Ae. Albopictus (Skuse). DHF vectors can be controlled with some ways, one of them by 
monitoring and examinating the larvae stage of the vector in community. Mubaraqah $\mathrm{R} \&$ Indarjo, I, (2013), study explained that effort to encourage the Larva Monitor (ABJ- DHF) can reduce the number of DHF larvae. The most frequent insecticide used is the chemical one (synthetic). Most of current study spotlight is to determine the resistance status of target organism, or insecticide potency concerning the effective concentration (Wahyuningsih \& Sihite, 2015).

Sensitivity of mosquito to insecticide is based on number of mortality at intervention. As $\mathrm{WHO}$ protocol year 1998 stated that the results of insecticide sensitivity test classified as vulnerable, tolerant, or resistant to insecticide if intervention resulted in $98-100 \%, 80-97 \%$, and less than $80 \%$ mortality rate, respectively. Many research report resistance or tolerant result regarding the use of certain insecticide in an area with a proportion of survived mosquito around 3-20\% of its total population. What exactly happened to the mosquitoes that survived after exposure of insecticide? In fact, our report showed that survived mosquitoes after exposed to chemical insecticide exhibit an increase in fecundicity and long life span compared to the one exposed to natural insecticide and control. Wahyuningsih \& Sihite (2015), explain that the survivors have profound strength and capability to reproduce. Longer life span will increase the chance for more copulation. It can be inferred that syntethic insecticide is no longer reduces mosquito population, instead it increases the population.

Syntethic insecticides circulating widely in markets, unfortunately without the proper use of it (Chang et al., 2014). Dengue fever, and filariasis are three of the most common mosquito-borne diseases worldwide. Malaria and lymphatic filariasis can occur as concomitant human infections while also sharing common mosquito vectors. The overall prevalence and health significance of malaria and filariasis have made them top priorities for global elimination and control programmes. Pyrethroid resistance in anopheline mosquito vectors represents a highly significant problem to malaria control worldwide. Several methods have been proposed to mitigate insecticide resistance, including rotational use of insecticides with different modes of action. Anopheles sinensis, an important malaria and filariasis vector in Southeast Asia, represents an interesting mosquito species for examining the consequences of long-term insecticide rotation use on resistance. We examined insecticide resistance in two An. Sinensis populations from central and southern China against pyrethroids, organochlorines, organophosphates, and carbamates, which are the major classes of insecticides recommended for indoor residual spray. We found that the mosquito populations were highly resistant to the four classes of insecticides. High frequency of kdr mutation was revealed in the central population, whereas no kdr mutation was detected in the southern population. The frequency of G119S mutation in the ace-1 gene was moderate in both populations. The classification and regression trees (CART claim that irrational dosage (sublethal) will induce resistance. According to Harfriani (2013), improper use of synthetic insecticide will promote resistance, cattle and human poisoning, environmental contamination, so we need to resolve the issues by searching for effective alternative insecticide to control the vectors.

Fogging is one way to chemically control Ae. aegypti by using synthethic insecticide. However, fogging is not recommended anymore as in 2013, Wahyudin, Head Section of Disease Control from Ministry of Health in Garut regency stated that fogging with commonly used insecticide is an ineffective way to exterminate DHF vectors, it induces mutation that promote resistancy of Ae. aegypti. "Even fogging does not kill those mosquitoes, they are immune to the kind of insecticide frequently used for fogging". Wahyudin adds, the emerging resistance is without a doubt caused by the frequent fogging that were done irregularly, so it put the risk of resistance on mosquito.

Other than that, control can be initated by killing vectors larvae to cut the chain of transmission by utilizing Abate (temephos). Abate is one of pesticide that are commonly 
used, its shape is sand granules that are spread in nearby water reservoir with dosage of $1 \mathrm{ppm}$ or 1 gram for 10 liters of water. Abate use still have potential for resistance as reported in Surabaya (Arif, 2011).

As mentioned above, an effort is urgently needed to search for alternative insecticide such as natural insecticide from plant that potentially poisonous for insect to control pest effectively and protect the environment. Natural insecticide is expected to be able to supress insect population to desirable ammount, that can be managed by its natural predator. Furthermore, natural insecticide is easily degradable that does not leave any heavy residue for environment (Ellyfas et al., 2012). As it serve as one of many environmental friendly solutions to restraint negative impact of chemical insecticide overusage, natural insecticide is safe for human and nature as its residue is easily decompose over shorttime (Kartimi, 2015). Suitable insecticide should have some of these requirement, namely strong and fast (quick knockdown effect) killing power with considerable amount of insect mortality, safe for human other living beings, stable compound (non-flammable), easy use, easy access, affordable, and does not have strong scent (Fadhlah \& Wahyuni, 2016).

Some studies focused on natural ingredients that are safe for human and environment, also avalaible in large quantity. Lots of plants can be used as insecticide, one of it is basil (Bahasa: kemangi; Ocimum basilicum forma citratum). In the past, basil is known as plant used as vegetable and eaten raw or even processed as medicine. Throughout literature records, basil contains active ingredients such as eugenol, flavonoid, saponin. Iffah et al., (2008) explain that basil bioactive compound, eugenol and methyl clavical has potential effect as insecticide. Both are the chemical compound that form atsiri oil extracted from basil. As Chaieb I (2017), describes that saponin nature, act as insecticide by affecting insects dietary habit. As it reduce the food uptake in gastrointestinal tract. Kristiana et al., (2008), illustrate that saponin can induce destruction of cell membrane that promote cytolysis. This disturb cells components that is intake and outake transport, affecting cell metabolism.
Flavonoid contains neurotoxic effects that cause stretch of the body (Gautam, K. et al, 2013). Eugenol can promote denaturation of cytoplasmic and necrosis of tissues.

Studies Iffah et al., (2008), found that basil extract influences growth of domestic fly. Basil extract affect mortality rate of domestic fly (Musca domestica) with concentration of $2.5 \%, 5 \%, 10 \%$, and $20 \%$ as the most effective one. Larvacide study by Kartika D \& Istianah S, (2014), utilizing basil leaf ethanol extract (Ocimum sanctum Linn) on Ae. aegypti larvae instar III showed promising $90.4 \%$ mortality in $2.500 \mathrm{ppm}$ dose. Similar intervention of larvicide research on Culexquinquefasciatus larvae instar III by Wijayani \& Istianah (2014), resulted in the most effective concentration of $98.4 \%$ mortality rate is at 5,000 ppm dose.

Based on previous studies above, this research aims to determine effectiveness of basil leaf extract in various concentration with knockdown time as indicator based on $\mathrm{KT}_{50}$ and effective spray concentration to kill $A e$. aegypti.

\section{Method}

Research conducted on Microbiology and Parasyte Laboratorium at Health Analyst Academy (AAK) of Fajar Foundation of Abdurrab University in Pekanbaru, and Integrated Lab of Chemistry Study of Muhammadiyah University in Pekanbaru in March to May 2016. Insects species for intervention is Ae. aegypti obtained from breeding sites of Microbiology and Parasytology Laboratorium of AAK Fajar Foundation of Abdurrab University. Basil leaves selected from basil plantation at Kertama st. Marpoyan Damai Sub-district, Pekanbaru.

Research revolved around utilization of basil leaf extract in controlling vectors by spraying Ae. aegypti without disregarding its life span affecting factors such as temperature and humidity. Research design was complete randomized method with four intervention concentrations namely, 5\%, 10\%, 25\% dan 50\%, Control (+) Baygon spray, Control (-) aquadest in four repetition.

Basil leaf extract created from 3.000 gr basil leaves, old basil leaves were washed with flowing tap water then dried and aired in temperature-controlled room to avoid direct 
contact of sunlight. Next, basil leaves dried in oven at $40^{\circ} \mathrm{C}$ degree for 24 hours. After that, dried leaves were minced until transformed into powder approximately as much as 450 grams. The powder then completely immersed (maseration) in ethanol $96 \%$ for about $3 \mathrm{x}$ 24 hours, then filtered and underwent the same step as third immersion. The filtered results were concentrated with vacuum rotary evaporator to obtain basil leaf extract and then stored in cabinet for later use.

To get $5 \%$ concentration, we took 0.25 $\mathrm{ml}$ of the extract and added $4.75 \mathrm{ml}$ aquades, finally we obtained total of $5 \mathrm{ml}$ solution. The same method was used to obtain $10 \%, 25 \%$, and $50 \%$ concentration. This solution then placed in a spray can before used on Ae. aegypti.

At the test, twenty Ae. aegypti mosquitoes placed in each box were sprayed with each concentration of basil extract in 4 repetitions. Observation of behavior, movement, and physical condition when they fell and die after intervention was noted for every 5 minutes in 1 hour. Quick knockdown time of basil extract was determined by the total amount of dead mosquito at the end of each intervention. Survived mosquitoes were left alone to die or killed by using Baygon.

Data analyzed by using varians analytic test with RAL, continued with one-way ANOVA test. Because the requirement of using one-way ANOVA test did not meet, we used alternative non-parametric test, Kurskal-Wallis and Spearman to show degree of correlation of both independent and dependent variables.

\section{Results and Discussion}

Observation showed step-by-step of death of Ae. aegypti after intervention. First the mosquito would fly fast, and fell in standing fashion and stop, legs and wings still moving but it could not fly anymore. After a few moments, it stayed still then dead with stiff body, body color turned to brownish resembling burned and dried specimen. Mortality rate of $A e$. aegypti in every 5 minutes for about 1 hour can be seen in Figure 1.

From Figure 1, we can see that 5\% concentration of extract have the lowest efficacy with longer duration of mosquito death and even after 60 minutes after spray lot of samples still alive. In the first 5 minutes, the mean death was 3.5 mosquitoes. Post-spray behavior showed that samples stood still, wings still moved, but cannot fly anymore. After few moments, they died (showed in Figure 2). The bodies were stiff and brownish. After 60 minutes, the mean death was 11.25 mosquitoes.

At $10 \%$ concentration, mean death of 5 minutes post-spray was 7 mosquitoes. Position were slant, supine, stay still, and few of their legs were still moving. After that, they died and the body would stiff with brownish color. At 55 minutes observation, the mean death was 20 mosquitoes.

At $25 \%$ concentration, mean death of 5 minutes post-spray was 9.25 mosquitoes. Position were slant, supine, stay still, and few of their legs were still moving. After that, they died

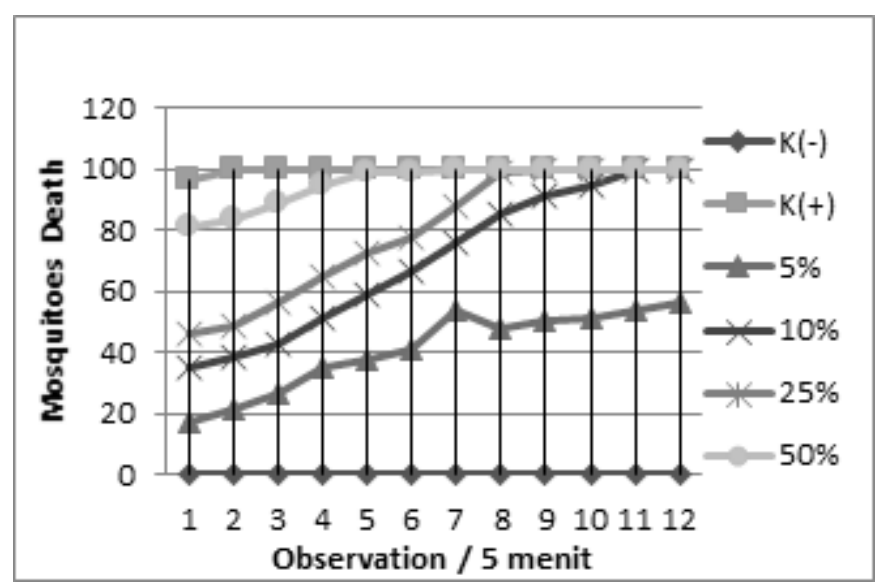

Figure 1. MortalityRate of Ae. aegypti in Various Concentration of Basil Leaves Extract. 


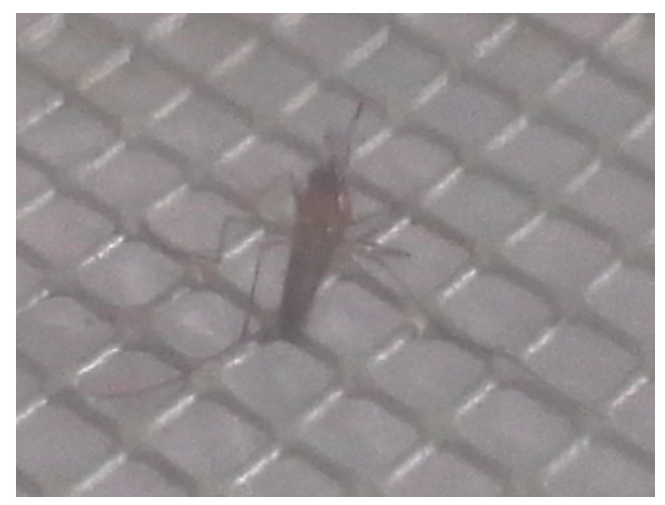

Figure 2. Mosquito Cannot Fly Anymore Caused by Active Compound of Basil Leaves Extract

and the body wiould stiff with brownish color. In this concentration the process of death was faster compared to $10 \%$ and $5 \%$ intervention. At 45 minutes observation, the mean death was 20 mosquitoes.

At $50 \%$ concentration, the fastest death occurred compared to all intervention. In 5 minutes post-spray, the mean death was 16.25 mosquitoses. At 25 minutes observation, the mean death was 20 mosquitos. Meanwhile, positive control showed death of 77 mosquitos and mean death of 19,25 at less than 5 minutes with fast death phase of stiff and spasm. Negative control showed no death in every repetition. All mosquitoes exhibited dodging behavior to the spraying.

According to data in Figure 1, different concentration showed different reaction. The mortality rate was in line with concentration increase. This conclude that, as concentration increased the potency of basil leaves extract against Ae. aegypti was getting stronger. Kruskall-Wallis test resulted in p-value $=0.001$ $<0.05$, means that the difference of increased concentration in acceleration of knockdown time was significant. Spearman test resulted in $\mathrm{p}$-value $=0.001<0.05$ with coefficient correlation +0.87 or $87 \%$, means that there exist high correlation of concentration basil leaves extract with knockdown time. In conclusion, the higher concentration of basil leaves extract, the faster knockdown time on Ae. aegypti mosquitoes.

Based on the average of the study

Table 1. Ae. aegypti Falling at Various Concentrations Treatment by Knockdown Time $\left(\mathrm{KT}_{50}\right)$

\begin{tabular}{lllllll}
\hline Minutes & $\mathbf{C}(-)$ & $\mathbf{C}(+)$ & $\mathbf{5 0 \%}$ & $\mathbf{2 5 \%}$ & $\mathbf{1 0 \%}$ & $\mathbf{5 \%}$ \\
\hline $\mathbf{5}$ & 0 & 19.25 & 16,25 & 9,25 & 7 & 3,5 \\
$\mathbf{1 0}$ & 0 & 20 & 16,75 & 9,75 & 7,75 & 4,25 \\
$\mathbf{1 5}$ & 0 & 20 & 17,75 & 11,25 & 8,5 & 5,25 \\
$\mathbf{2 0}$ & 0 & 20 & 19 & 13 & 10,25 & 7 \\
$\mathbf{2 5}$ & 0 & 20 & 19,75 & 14,5 & 11,75 & 7,5 \\
$\mathbf{3 0}$ & 0 & 20 & 19,75 & 15,5 & 13,25 & 8,25 \\
$\mathbf{3 5}$ & 0 & 20 & 20 & 17,5 & 15,25 & 8,75 \\
$\mathbf{4 0}$ & 0 & 20 & 20 & 19,75 & 17 & 9,5 \\
$\mathbf{4 5}$ & 0 & 20 & 20 & 20 & 18,25 & 10 \\
$\mathbf{5 0}$ & 0 & 20 & 20 & 20 & 19 & 10,25 \\
$\mathbf{5 5}$ & 0 & 20 & 20 & 20 & 20 & 10,75 \\
$\mathbf{6 0}$ & 0 & 20 & 20 & 20 & 20 & 11,25 \\
\hline
\end{tabular}


repetitions on Table 1, we didn't find any Ae. aegypti fell in $\mathrm{C}(-)$ while in $\mathrm{C}(+)$, the $\mathrm{KT}_{50}$ was less than 5 minutes. The $\mathrm{KT}_{50}$ in different concentrantions were less than 5 minutes in $50 \%$ concentrations, between 11-15 minutes in $25 \%$ concentrations, between 16-20 minutes in $10 \%$ concentrations, and between $41-45$ minutes in $5 \%$ concentrations. This showed that the difference in concentrations of basil leaf extract had different effects on the number of Ae. aegypti falling, as well as for each treatment and repetitions.

From Table 2, we could determine the effectiveness level of four different concentration of basil leaf extract and positive control based on Insectiside Knockdown Time ${ }_{50}\left(\mathrm{KT}_{50}\right)$. Basil leaf extract in $5 \%$ concentrations had $\mathrm{KT}_{50}$ in 41-45 minutes which included as insectiside score 1 or had no knockdown effect, whereas $10 \%$ concentrations had $\mathrm{KT}_{50}$ in $16-20$ minutes which was insectiside score 2 or had no knockdown effect, whereas in $25 \%$ concentrations the $\mathrm{KT}_{50}$ was in 11-15 minutes which was insectiside score 3 or had weak knockdown effect, whereas $50 \%$ concentrations had $\mathrm{KT}_{50}$ in less than 5 minutes with insectiside score 5 or quick knockdown effect. In $\mathrm{C}(+)$ (Baygon) the $\mathrm{KT}_{50}$ was less than 5 minutes with insectiside score 5 or quick knockdown effect. From the four treatment concentrations based on Table 2 above, it can be known that the effective concentration of basil leaf extract to be able to make Ae. aegypti mosquitoes falling with insecticide score 5 or had quick knockdown effect was the concentration of $50 \%$.

Theobservation results of the Ae. aegypti mortality process based on various treatment concentrations showed that the number of deaths increased with increasing treatment concentration. Based on the graph in Table 1, there was an increase in mosquito mortality as the concentration of basil leaf extract increased because the higher concentration of basil leaf extract the higher content of toxic compounds absorbed by the body of Ae. aegypti, both as contact poisons, respiratory poisons and stomach poisons so it would accumulated faster and had more toxic effect in the body of the mosquito, and ultimately lead to death.

From the results of this study, the level of toxicity in insecticidal effects of basil leaf extract increased in higher concentration. The length of exposed time to insecticides will also add to the toxicity effect of basil leaf insecticides. The toxic compounds absorption would affect the Ae. aegypti mosquitoes body's metabolism and cause mortility. This was consistent with the results of the study by Iffah et al., (2008), about the effect of Basil extract on the development of house flies. The more house fly larvae absorb the toxic compounds contained in basil leaf extract, the more house fly larvae that died since the compound would affected the metabolic process of flies that led to death. Likewise, this study was consistent with the study of Alindatus et al., (2013) regarding the influence of Bintaro leaf extract on the development of Grayak caterpillars, which was the higher the toxic compounds absorbtion from bintaro leaf extract the greater effect on the metabolism of caterpillars that will eventually led to death.

This study was intended to explore further and specific information about the effectiveness of Basil leaf extract natural insecticides properties against Ae. aegypti mosquitoes through "Knockdown Time" (time needed to make test animals fall). Time needed to make half of the mosquitoes fell are called $\mathrm{KT}_{50}$ or Median Knockdown time. $\mathrm{KT}_{50}$, then could be used to determine the effectiveness of

Table. 2 Insecticide of Basil Leaf Extract (Ocimmum Basillum form citratum) based on $\mathrm{KT}_{50}$

\begin{tabular}{lllll}
\hline Control Group & $\begin{array}{l}\text { KT50 } \\
(\text { minutes })\end{array}$ & $\begin{array}{l}\text { Knockdown } \\
\text { Effect }\end{array}$ & $\begin{array}{l}\text { Insecticide } \\
\text { Score }\end{array}$ & Interpretation \\
\hline $5 \%$ Concentrations & $41-45$ & - & 1 & - \\
$10 \%$ Concentrations & $16-20$ & - & 2 & - \\
$25 \%$ Concentrations & $11-15$ & + & 3 & Weak Knockdown \\
$50 \%$ Concentrations & $<5$ & +++ & 5 & Quick Knockdown \\
Positive Control & $<5$ & +++ & 5 & Quick Knockdown \\
\hline
\end{tabular}


an insecticide using the Insecticide Score based on WHO criteria.

From the observation, there were various ways of the mosquito's death process after spraying the Basil leaf extract: (1) When different concentrations were sprayed, mosquitoes would flew quickly, some fall in a standing position, it was still but the legs and wings looked still moving and the mosquitoes were unable to fly anymore. After a while the Ae. aegypti mosquito fell and died. The body of a mosquito looked stiff, dry and brown colored. This was probably caused by the content of flavonoids as bioactive compounds in the extract of Basil leaves which containing alcohol that entering the mouth and through the respiratory tract and through the spiracles contained on the surface of the skin of mosquitoes' body. It could cause nerve disorders which made the wings wither and stiff, led to the inability of the mosquitoes to fly again.

This study was in line with the study of Gautam et al., (2013) conducted on Anopheles and Ae. aegypti larvae which were given extracts of Vitex negundo plant containing flavonoids which showed integument disintegration which was associated with loss of chitin layer and abnormal stretching of larval bodies. This was because of the neurotoxic effects of Vitex negundo plant extracts containing flavonoids. Hollingworth (2001) in Utami S (2010), described rotenone as a flavonoid compound which had a deadly effect on insects. He stated that rotenone worked as a poison for cell respiration, which inhibits electron transfer in $\mathrm{NADH}$-coenzyme subquinone reductase (complex 1) of the electron transfer system in the mitochondria.

Other compounds contained in Basil that had effects on the mortality of Ae. aegypti mosquitoes were saponin. The saponin compound tasted bitter and could damage cell membranes and disrupt the metabolic process of Ae. aegypti mosquitoes and reduce the surface tension of the mucous membrane of the digestive tract so that the tract's walls become corrosive led to its death. Chaieb I, (2017) reported that saponin compounds could act as insecticides by changing their eating behavior by inhibited food uptake in the digestive tract. Saponin could also inhibit larval stage growth by interfering with the molting larva stage. Furthermore Chaieb I, et al., (2007) added that saponin could cause molecular disorganization in Schistocereagregaria and Spodoptera lottoralis. Saponin were strong surfactant in which low concentrations could be toxic to mammals because they caused red blood cells hemolysis (Iffah et al., 2008). Pratama \& Dwi A, (2009), explained that saponin could damage cell membranes and disrupt the metabolic processes of insects whereas polyphenols were inhibitors of insects digestive tract. Saponin was a secondary metabolite compound produced by different plant species, especially dicotyledonous plants and acts as part of a defense system and was included in a large group of plant protective molecules.

From the results of the second observation (2), after spraying the Basil leaf extract to Ae. aegypti mosquitoes body's, they would flew fast, fall down and died. The mosquito's body was burning, brownish, stiff and dry. This was caused by the compounds contained in Basil extract, Eugenol. Eugenol is a phenol compound with an alcohol group.

Eugenol contained in basil leaf extract functioned as an insecticide by working as a contact poison through the body surface of the Ae. aegypti mosquito. Eugenol (phenol) was easily absorbed through the skin and could cause denaturation by destroying the integument resulting in a burning effect. Agusta (2000), explained that eugenol, known as allyl guaiacol worked by inhibiting oxidation flavin-Linked toxins \& NAD-linked substrates causing cytoplasmic denaturation and tissue necrosis. Contact toxin would seep into the body of the animal through the outer skin and the animal would die if touched its skin. According to Department of Parasitology FKUI (2008), contact poison was usually used to eradicate insects that had suction-type mouth. Insecticides entered through the exoskeleton into the body of the insect through tarsus. Toxins would seep into the body through the outer skin, penetrated the blood vessels or through toxic breathing in the body led to the insect death.

Eugenol (phenol) could cause burn and toxic defects and caused allergies if exposed to the skin. This substance caused the body of 
Ae. aegypti to appear brown, stiff because it affected the nervous system of mosquitoes. This results in the death of Ae. aegypti mosquitoes in dry physical form and brownish color that looked like burnt. Iffah et al., (2008) explained that eugenol was a phenol compound that had an alcohol group so that it could weaken and disrupt the nervous system. In the research on house fly larvae, house fly larvae that exposed to basil leaves extracts would die and it looked like the body of the larvae was stiff because it affects the nervous system of the larva and the body looked like a brownish burning color.

The research conducted by Iffah et al., (2008) showed us the effect of Basil leaf extract on the development of house flies (Musca domestica) with a concentration of $2.5 \%, 5 \%$, $10 \%$ and $20 \%$ which were carried out four times. The results of the study found that Basil leaves influence the mortality of most house fly larvae, the lowest ability of ecdysis and eclosion of fly (inhibits the development of pupae) was a concentration of $20 \%$. The conclusion of this research was that the best concentration of Basil leaf extract as a fly larvasida of Musca domestica was a concentration of $20 \%$.

Research by Wijayani, LA \& Istianah, S. (2014) about the larvicidal effect of ethanol extract of Basil leaves on instar III larvae of Culex quinquefasciatus with concentrations of $5000 \mathrm{ppm}, 4500 \mathrm{ppm}, 4000 \mathrm{ppm}, 3500 \mathrm{ppm}$, 3000 ppm, 2000 ppm, 1500 ppm, 1000 ppm, with control using Tween $0.25 \%$ in aquadest which was done with three repetitions. In this study, 25 instar III larvae of C. quinquesfasciatus were used which were exposed to the extract for 24 hours. The results of this research showed that the ethanol extract of Basil leaves had a larvacidal effect on instar III larvae of C. quinquesfasciatus. The most effective concentration in killing instar III larvae of $C$. quinquefasciatus was at a dose of $5000 \mathrm{ppm}$ which was equal to $98.4 \%$.

Other studies on the larvacidal effect of the ethanol extract of Basil leaves (Ocimum sanctum Linn) on Aedes aegypti instar III larvae were carried out by Kartika \& Istianah, (2014). It consisted of preliminary research and final research. A preliminary study was conducted to determine the concentration range of the test material that killed test larvae of $10 \%$ -
90\% which would be used in the final test. The highest concentration in this preliminary study was $5000 \mathrm{ppm}$ which was a concentration that was estimated to cause death $>90 \%$ and dead larvae can still be seen because the solution was not too thick. The final research was carried out on five treatment groups with variations in the concentration of Basil leaf extract which was able to kill test larvae of $10 \%-90 \%$ based on preliminary tests of $50 \mathrm{ppm}, 1000 \mathrm{ppm}, 1500$ ppm, $2000 \mathrm{ppm}$ and $2500 \mathrm{ppm}$. The results of the analysis showed that the ethanol extract of Basil leaves can kill Ae. aegypti instar III larvae up to $90.4 \%$ at $2500 \mathrm{ppm}$.

Research on the potential test of fragrant pandan extract as a vegetable insecticide against house flies to determine Knockdown Time $\left(\mathrm{KT}_{50}\right)$ carried out by Fadhlah $\mathrm{H} \&$ Wahyuni, D (2016). It showed that fragrant pandan extract had the potential as an insecticide against house flies at a concentration of $75 \%$ with quick knockdown time. The greater the concentration of fragrant pandan extract, the faster the "Knockdown Time" was.

Kristiana et al., (2008) stated from the results of the study found that administration of Bintaro leaf extract significantly affected the mortality of Ae. aegypti larvae both at 24, 48 and 72 hours after treatment. The optimal concentration to kill Ae. aegypti mosquito larvae was $1.0 \%$ concentration which could cause mosquito larvae Ae. aegypti mortality with an average mortality of $85 \%$ within 24 hours after treatment.

Overall, it can be concluded that the active substances contained in Basil leaf extract had potential as vegetable insecticides. This was because the higher active molecules of Basil leaf extract enter the body of Ae. aegypti mosquitoes, the greater the effect. In addition, the increased exposure time of Basil leaf extract would increase the number of molecules of active substances that enter the body of Ae. aegypti mosquitoesto led to greater toxic effects.

In its use as fresh vegetables, it turns out that Basil leaves had benefits as a vector control, especially Ae. aegypti mosquitoes as seen from the test results. The results of this study indicated that Basil leaf extract in spray form had the effectiveness in Ae. aegypti mosquito vector control. The effectiveness 
of Basil leaf extract showed that it contained active compounds that could be used as vegetable / natural insecticides. Besides, Basil plants were common, the residues were easily biodegradable, did not pollute the environment, were safe for other living creatures and did not cause any resistance to Ae. aegypti mosquitoes.

Chang et al., (2014) stated that natural insecticides were necessary to suppress the dangers of insecticides which could lead to resistance and will slow down the genetic adaptation process in vectors. In his report entitled "Multiple Resistance and Complex Mechanism of Anopheles sinensis Mosquito: a Major Obstacle to Mosquito-Borne Disease Control and Elimination in China" he emphasized that there were two mechanisms thought to cause resistance in mosquitoes. First: the use of inappropriate doses which made mosquitoes adaptable by performed a series of metabolite detoxification processes or quickly eliminates the rest of toxins, in this case, chemical insecticide very fast, second: inappropriate doses will made mosquitoes adapt to improve survival against sub lethal doses over time which called incentification. Both of these would affect the cyclical power of the mosquito's immune power and eventually bequeathed to the next generation. The resistance that occurred due to DNA metabolism was finally known as the gene mutation in the G119S and L1014 aces-1. Chang recommended consistently replacing the use of chemical insecticides and diversifying them with natural insecticides so that they were expected to create synergy effect between chemistry and nature, at least prolonging the duration of the genetic adaptation process for mosquitoes to reduce the risk of the 2 mechanisms described above. Based on Chang's research results above, it was clear that natural insecticides were necessary to suppress the dangers of insecticides which led to resistance and will slow down the genetic adaptation process in vectors. Besides resistance, there were still other problems, such as toxic effects of insecticides that occurred not only in insects, humans, and also on the environment and even the balance of the ecosystem.

In terms of availability, Basil plants was a common and ubiquitous plants. Utami, (2010) explained that there were several things that need to be considered in using plants as a potential insecticide, namely: (1) Plants that had the potential as vegetable insecticides should be easily obtained in nature and were everywhere. (2) Biomass could be obtained in abundant conditions. (3) Easy to decompose in nature so it did not pollute the environment and was relatively safe for humans and pets because the residue was easily disappeared.

Of course this was also supported by various other theories and literature, which stated that Basil leaves were very beneficial for the community, in the use as alternative plant-based insecticides that environmentally friendly, especially in controlling Ae. aegypti mosquitoes and was could potentially be used as alternative substitute for fogging.

\section{Conclusion}

Based on the research, it can be concluded that Basil leaves extract had knockdown power on Ae. aegypti mosquitoes. The $\mathrm{KT}_{50}$ and Insecticide Score on different concentrations were as follow: $5 \%$ concentration had $\mathrm{KT}_{50}$ between 41-45 minutes with insectiside score 1 / no knockdown effect, $10 \%$ concentration had $\mathrm{KT}_{50}$ in 16-20 minutes with insectiside score $2 /$ no knockdown effect, $25 \%$ concentration had $\mathrm{KT}_{50}$ in 11-15 minutes with insectiside score 3 / weak knockdown effect, 50\% concentration had $\mathrm{KT}_{50}$ in less than 5 minutes with insectiside score 5 / quick knockdown effect. The 50\% concentration of Basil leaf extract is the most effective as insecticide against Ae. aegypti because of the large amount of killing power with a short time and quick knockdown effect.

Basil leaf extract (Ocimmum Basillum form citratum) could be used by the community as an alternative plants-based insecticide that are environmentally friendly to control $A e$. aegypti mosquitoes and potentially also as an alternative to fogging.

\section{Acknowledgments}

Author would like to thank the DRPM Kemenristek DIKTI for funding this research and also the Laboratory of Microbiology \& Parasitology of the AAK Fajar Foundation of Abdurrab Pekanbaru University and the Integrated Laboratory of Chemistry Study Program at the University of Muhammadiyah Riau Pekanbaru for allowing the research to take place there. 


\section{References}

Agusta, A., 2000. Minyak Atsiri Tumbuhan Tropika Indonesia. Bandung: ITB.

Alindatus, N., Purwani, K.I., Wijayawati, L., Arief, J., Hakim, R., \& Indonesia, S., 2013. Pengaruh Ekstrak Daun Bintaro (Cerbera Odollam) Terhadap Perkembangan Ulat Grayak (Spodoptera Litura F). Jurnal Sains Dan Seni Pomits, 2(2), pp.111-115.

Arif, D.N., 2011. Kematian Larva Aedes aegypti Setelah Pemberian Abate Dibandingkan dengan Pemberian Serbuk Serai. Jurnal Kesehatan Masyarakat, Kemas, 7(1), pp.9196.

Chaieb, I., \& Protection, L.D., 2017. Saponins as Insecticides: A Review Saponins as Insecticides : A Review, Tunisian. Journal of Plant. Protection, 5, pp.39.

Chaieb, I., Trabelesi, M., Ben Halima-Kamel, M., \& Ben Hamouda, M.H., 2007. Histological Effects of Cestrum Parqui Saponin on Schistocere agregaria and Spodoptera lottoralis. Biol. Sci. Journal, 7(1), pp.95-101.

Chang, X., Zhong, D., Fang, Q., Hartsel, J., Zhou, G., Shi, L., \& Yan, G., 2014. Multiple Resistances and Complex Mechanisms of Anopheles sinensis Mosquito: A Major Obstacle To Mosquito-Borne Diseases Control and Elimination in China. Plos Neglected Tropical Diseases, 8(6).

Departemen of Parasitologi FKUI., 2008. Buku Ajar Parasitologi. Edisi Keempat. Jakarta: Balai Penerbit FK UI.

Ellyfas, K., Suprobowati, O.D., \& Joko, S.C.B.U., 2012. Pengaruh Pemberian Ekstrak Buah Nanas (Ananas Comosus L. Merr) Terhadap Kematian Larva Aedes aegypti. Jurnal Analis Kesehatan, 1(2), pp.62-67.

Fadhlah H., \& Wahyuni, D., 2016. Uji Potensi Ekstrak Pandan Wangi (Pandanus amariliforus Roxb) Sebagai Insektisida Nabati Terhadap Lalat Rumah (Musca domestica) dengan Metode Semprot. Jurnal Al Tamini Kesmas, 5(1), pp.1-9.

Gautam, K., Kumar, P., \& Poonia, S., 2013. Larvicidal Activity and Gc-Ms Analysis of Flavonoids of Vitex negundo and Andrographis paniculata Against Two Vector Mosquitoes Anopheles stephensi and Aedes aegypti. Journal of Vektor Borne Diases, 50, pp. 171-178.

Harfriani, H., 2013. Efektivitas Larvasida Ekstrak Daun Sirsak Dalam Membunuh Jentik Nyamuk. Jurnal Kesehatan Masyarakat, Kemas, 7(2), pp.164-169.

Iffah, D., Gunandini, D.W.I.J., \& Kardinan, A.,
2008. Pengaruh Ekstrak Kemangi (Ocimum Basilicum forma citratum) terhadap Perkembangan Lalat Rumah (Musca domestica L.). Jurnal Entomologi Indonesia, 5(1), pp.36-44.

Jacob, A.D., Pijoh, V., \& Wahongan., 2014. Ketahanan Hidup dan Pertumbuhan Nyamuk Aedes Spp Pada Berbagai Jenis Air Perindukan. Jurnal E-Biomedik (EBM), 2(3).

Kartika, D., \& Istianah, S., 2014. Efek Larvasida Ekstrak Etanol Daun Kemangi (OcimumSanctum Linn) terhadap Larva Instar III Aedes aegypti. JKKI, 6(1), pp.3745.

Kartimi., 2015. Pemanfaatan Buah Bintaro Sebagai Biopestisida Dalam Penanggulangan Hama Pada Tanaman Padi Di Kawasan Pesisir Desa Bandengan Kabupaten Cirebon. Prosiding Seminar Nasional Pendidikan Biologi Univ. Muhammadiyah Malang, pp.101-111.

Kristiana, I.D., Ratnasari, E., \& Haryono, T., 2008. Pengaruh Ekstrak Daun Bintaro (Cerbera odollam) terhadap Mortalitas Larva Nyamuk Aedes aegypti. Lantera Bio, 4(2), pp.131-135. Mubaraqah, R., \& Indarjo, S., 2013. Upaya Peningkatan Angka Bebas Jentik (AJB) DBD Melalui Penggerakan Jumantik. Unnes Journal of Public Health, 2(3), pp.1-9.

Pratama, B.A., \& Astuti, D.A., 2009. Pemanfaatan Ekstrak Daun Pandan Wangi (Pandanus amaryllifolius Roxb) Sebagai Larvasida Alami. Jurnal Kesehatan, 2(2), pp.115-124.

Utami, S., 2010. Aktifitas Insektisida Bintaro (Carbera odollam Gaertn) Terhadap Hama Eurema spp. pada Skala Laboratorium. Jurnal Penelitian Hutan Tanaman, 7(4), pp.211-220.

Utami, S., Syaufina, L., \& Haneda, N.F., 2010. Daya Racun Ekstrak Kasar Daun Bintaro (Carbera odollam Gaertn) Terhadap Larva Spodoptera litura Fabricius. Jurnal Ilmu Pertanian Indonesia, 15(2), pp.96-100.

Wahyuningsih, N.E., \& Sihite, R.A., 2015. Perbedaan Respon Aedes aegypti (Linnaeus) (Diptera : Culicidae), terhadap Paparan Anti Nyamuk Bakar dan Bunga keluwih (Artocarpus camansi, Blanco). Jurnal Entomologi Indonesia, 12(1), pp.20-30.

Wijayani, L.A., \& Istianah, S., 2014. Efek Larvisidal Ekstrak Etanol Daun Kemangi (Ocimumsanctum Linn) Terhadap Larva Instar III Culexquinquefasciatus. Jurnal Biomedika, 6(6), pp.5-8. 